\title{
February 1939: the start of the first journal publishing research in virology
}

\author{
Tim Skern ${ }^{1}$
}

Received: 25 February 2019 / Accepted: 27 February 2019 / Published online: 19 March 2019

(C) Springer-Verlag GmbH Austria, part of Springer Nature 2019

February 2019 marks the $80^{\text {th }}$ anniversary of the publication of the first issue of Archives of Virology, then under its original name "Archiv für die gesamte Virusforschung". To celebrate this anniversary of the first journal to publish scientific research on virology, Springer Vienna has asked me to organise a one-day symposium. In keeping with the original name of the journal, I decided not to focus on one particular area of virology but instead to cover a wide range of topics as possible. We are therefore delighted that the following esteemed scientists from many different areas of virology have accepted our invitation to speak at the symposium:

\begin{tabular}{ll}
\hline Speaker & Research topic \\
\hline Wendy Barclay (London) & Antiviral resistance in influenza virus \\
Sarah Butcher (Helsinki) & Structural studies on parechovirus \\
Linda Dixon (Pirbright) & African swine fever virus \\
Adrian Fox (York) & Viral evolution and agriculture \\
Susan Hafenstein (Penn State) & $\begin{array}{l}\text { Papillomavirus structure } \\
\text { Edward Holmes (Sydney) }\end{array}$ \\
Viral evolution \\
Marie-Paule Kieny (Paris) & $\begin{array}{c}\text { Challenges of developing anti-viral } \\
\text { drugs }\end{array}$ \\
Amadou Sall (Dakar) & $\begin{array}{c}\text { Mosquito-transmitted diseases and } \\
\text { Ebola virus }\end{array}$ \\
Quentin Sattentau (Oxford) & HIV pathogenesis and vaccine design \\
Jolanda Smit (Groningen) & Human immune system: interac- \\
& tion with dengue and chikungunya \\
& viruses \\
Alexandra Trkola (Zurich) & Antibodies and HIV neutralisation \\
\hline
\end{tabular}

The symposium is to take place in Vienna on Monday, 25th November 2019 in the Van Swieten Room of the Medical University Vienna. More information on the symposium

Tim Skern

timothy.skern@muv.ac.at

http://www.mfpl.ac.at/skern

1 Max F. Perutz Laboratories, Medical University of Vienna, Dr. Bohr-Gasse 9/3, 1030 Vienna, Austria along with details on how to register (participation is free) on-line can be found at: http://www.springer.com/705.

Information on accommodation in Vienna and on Vienna in general can be found at: https://www.wien.info/en

The beginnings of "Archiv für die gesamte Virusforschung"

The founding editor-in-chief was Dr. Robert Doerr, born in 1871 in Técsö in the South-Eastern part of the AustroHungarian Empire (now in the Ukraine), Professor of hygiene and immunology at the University of Basel from 1919 to 1943 . He was also editor of the two volumes of "Handbook of Virology Research" published in 1938 and 1939 and which he continued until his death in 1952. Robert Schlesinger has written a fascinating and very personal account, including some amusing anecdotes, of his time with Robert Doerr in Basel [10].

The founding editorial board of Archives of Virology assembled by Doerr reads like a Who's Who of pioneering virologists and bacteriologists active in the 1930s, comprising the following eminent scientists: Samuel P. Bedson (London), James Craigie (Toronto), André Gratia (Liege), Curt Hallauer (Bern), Richard E. Shope (Princeton), Kenneth M. Smith (Cambridge), Wendell M. Stanley (Princeton), William J. Tulloch (Dundee), Otto Waldmann (Greifswald).

Each of the above scientists carried out ground-breaking work in their particular area and laid the basis for the developments of the field in subsequent decades. Samuel P. Bedson in the 1920s developed diagnostic tools for foot-andmouth disease virus and examined the causative agent of psittacosis which had been brought into the United Kingdom by infected psittacine birds [2]. Otto Waldmann in the 1930s also worked on foot-and-mouth disease virus, developing a vaccine using inactivated virus preparations that provided a much longer lasting immunity than that with previously used immune sera [5].

André Gratia revealed in a seminal experiment that the filterable agents identified by Twort and d'Hérelle were 
different types of bacteriophage. Gratia subsequently examined the phenomenon of lysogeny, began to explore bacteriophage genetics and then later applied his knowledge and techniques to plant and insect viruses [4]

Plant viruses were also covered by members of the editorial board. Fundamental work was carried out by Kenneth Smith who began by characterising viruses infecting potatoes and then progressed to identify many well-known viruses of agricultural importance [6]. In contrast, Wendell Stanley, possibly the most well-known of the members of the founding editorial board, obtained and examined crystals of tobacco mosaic virus (TMV) and showed that the material in the crystal was proteinaceous and infectious [11]. He was awarded the Nobel Prize in chemistry in 1946 for the preparation of viruses in a pure form. He did not however detect the RNA in the virus crystals and took a long time to accept the ribonucleoprotein nature of TMV. A bitter and longrunning dispute with Bawden and Pirie, who had showed that TMV is a ribonucleoprotein complex, ensued [9].

The isolation and examination of influenza virus was, not surprisingly given the temporal proximity to the Spanish flu pandemic, a topic that was common to several members of Doerr's editorial board. Richard Shope identified influenza A virus in pigs 1931 [12]. Shope also made a second crucial discovery by identifying papillomaviruses in rabbits and showed that the filterable agents could induce tumours [12]. Shope also "infected" his son Robert with the "virology virus", so much so that Robert Shope has been reported to have "identified more novel viruses that any person previously" [8].

In the same year that Richard Shope identified influenza in pigs, Curt Hallauer was able to propagate Geflügelpestvirus (i.e. avian influenza virus) outside the natural host [3]. Hallauer continued to examine and develop tissues for propagating viruses such as poliovirus and examining viral mutants with reduced virulence [3]. Following Doerr's death in 1952, Hallauer became the second editor-in-chief of "Archiv für die gesamte Virusforschung".

William Tulloch was involved in the development of sera against vaccinia virus for diagnosis as well as carrying out crucial studies on the nature of strains of diphtheria that were causing epidemics in Northern England and Scotland in the early 1930s [7]. James Craigie, a student of
Tulloch, extended the work on the immunology of vaccinia and variola, revealing antigens that could be released from viral particles and developing a complement-fixation test for variola from crusts that was ten times more sensitive than the current ones then in use [1].

Researching on the contributions of these eminent virologists to our field, it is indeed a tremendous honour to carry out the role of editor-in-chief of Archives of Virology. I hope that the symposium in November will attain the same standard set by the founding editors. I look forward to what promises to be a very stimulating day.

\section{References}

1. Andrewes C (1979) James Craigie 25 June 1899-26 August 1978. Biogr Mem Fellows R Soc 25:233-240

2. Downie AW (1971) Obituary. S. P. Bedson, 1886-1969. J Gen Microbiol 65:1-3

3. Gard S, Meyer KF, Mayr A, Rowe WP (1970) Prof. Dr. Dr. h. c. Curt Hallauer zum 70. Geburtstag. Archiv für die gesamte Virusforschung 31:1-3

4. Gratia JP (2000) Andre Gratia: a forerunner in microbial and viral genetics. Genetics 156:471-476

5. Horzinek MC (1995) The beginnings of animal virology in Germany. Arch Virol 140:1157-1162

6. Hull R (1982) Kenneth Manley Smith, 1892-1981. Microbiology 128:431-432

7. McLeod JW (1966) Prof. W. J. Tulloch. Nature 212:883-884

8. Murphy FA, Calisher CH, Tesh RB, Walker DH (2004) In Memoriam Robert Ellis Shope 1929-2004. Emerg Infect Dis 10:762-765

9. Pennazio S, Roggero P (2000) The discovery of the chemical nature of tobacco mosaic virus. Riv Biol 93:253-281

10. Schlesinger RW (1997) Robert Doerr-prophet of the nature of viruses, founder of the "Archives of Virology". Arch Virol 142:861-873

11. Stanley WM (1946) The isolation and properties of crystalline tobacco mosaic virus. Nobel Media AB 2019, Stockholm. http:// www.nobelprize.org/prizes/chemistry/1946/stanley/lecture/. Accessed 13 Mar 2019

12. Van Epps HL (2006) Influenza: exposing the true killer. J Exp Med 203:803

Publisher's Note Springer Nature remains neutral with regard to jurisdictional claims in published maps and institutional affiliations. 